\title{
Dynamics of structural, functional and vegetative changes of heart under the influence of combined therapy with the use of ursodeoxycholic acid and L-arginine in patients with coronary heart disease associated with nonalcoholic fatty liver disease
}

\author{
N. S. Mykhailovska, L. Ye. Miniailenko \\ Zaporizhzhia State Medical University, Ukraine
}

Key words:

coronary

artery disease,

nonalcoholic

fatty liver disease,

hemodynamics,

autonomic

nervous system,

ursodeoxycholic

acid, arginine.

Pathologia 2017; 14 (2), 142-148

DOI:

10.14739/2310-1237

2017.2.109268

E-mail:

luba89@gmail.com

Objective: to study the effect of the ursodeoxycholic acid and L-arginine combination on the background of basic therapy on the structural and functional state of the heart and indicators of the autonomic nervous system in patients with coronary heart disease combined with the non-alcoholic fatty liver disease.

Methods: The study involved 56 patients with coronary heart disease (CHD) and nonalcoholic fatty liver disease (NAFLD). Patients were randomized into two groups. Patients in the $1^{\text {st }}$ group $(n=30)$ received only basic therapy of coronary heart disease, patients in the $2^{\text {nd }}$ group $(n=26)$ in addition to basic therapy were prescribed with UDCA and L-arginine.

All patients underwent daily ECG monitoring and two-dimensional echocardiography. Statistical data processing was carried out using the program package Statistica 6.0.

Results: In the $2^{\text {nd }}$ group after 3 months of treatment there were observed decrease in indicators: myocardial stiffness index by $45 \%$, Va by $7.4 \%$, mean heart rate in both the active (11.72\%) and the passive (8\%) periods, the number (80 \%) and duration $(85 \%)$ of tachycardia episodes, total number of ventricular $(84 \%)$ and supraventricular $(63 \%)$ extrasystoles per day, duration of the ST depression (by $55 \%$ ) and the duration of its maximum episode (by $75 \%$ ) and LF/HF ratio to $24 \%$ in the active and $27 \%$ in the passive period along with an increase of indicators: Ve by $7.4 \%$, SDNNi in both active $(18 \%)$ and passive $(20 \%)$ periods $(p<0.05)$.

Conclusions: The positive effects of adding UDCA and L-arginine to basic therapy in patients with coronary artery disease and NAFLD include improved diastolic function, decreased myocardial ischemia, decreased myocardial stiffness and the number of ventricular and supraventricular extrasystoles, as well as increased total VPS, normalization of the sympathetic-parasympathetic balance by increasing the parasympathetic component of the cardiovascular system.

Ключові слова:

ішемічна хвороба серця, неалкогольна жирова хвороба печінки, гемодинаміка, вегетативна нервова система, урсолезоксихолева кислота, аргінін.

Патологія. - 2017. T. 14, № 2(40). C. $142-148$

\section{Аинаміка структурно-функціональних і вегетативних змін серця під впливом комбінованої терапії урсодезоксихолевою кислотою та L-аргініном у хворих на ішемічну хворобу серця, асоційовану з неаккогольною жировою хворобою печінки}

\section{Н. С. Михайловська, ^. Є. Міняйленко}

Мета роботи - вивчити вплив комбінації урсодезоксихолевої кислоти та L-аргініну на тлі базисної терапії на структурно-функціональний стан серця та показники вегетативної нервової системи у хворих на ішемічну хворобу серця, що поєднана з неалкогольною жировою хворобою печінки.

Матеріали та методи. У дослідженні взяли участь 56 пацієнтів з IXC і НАЖХП. Пацієнти рандомізовані у дві групи. Пацієнти 1 групи ( $\mathrm{n}=30)$ отримували тільки базисну терапію ішемічної хвороби серця, пацієнтам 2 групи $(\mathrm{n}=26)$ додатково до базисної терапії призначались УДХК і L-аргінін.

Усім пацієнтам проведені добовий моніторинг ЕКГ за Холтером і двовимірна ехокардіографія з імпульсно-хвильовою доплерографрією. Статистичні дані опрацьовані за допомогою пакета програм Statistica 6.0.

Результати. У 2 групі після 3 місяців лікування спостерігали вірогідне зниження показників: індексу жорсткості міокарда - на $45 \%$, Va - на 7,4 \%, середньої частоти серцевих скорочень як в активному $(11,7 \%)$, так і в пасивному (8 \%) періодах, кількості (80 \%) і тривалості (85 \%) епізодів тахікардії, загальної кількості шлуночкових (84 \%) та суправентрикулярних (63 \%) екстрасистол за добу, тривалості депресії сегмента ST (на 55 \%) і тривалості ї̈ максимального епізоду (на 75 \%) і співвідношення LF/HF на 24 \% в активному та 27 \% у пасивному періодах, поряд із вірогідним збільшенням показників: Ve - на 7,4 \%, SDNNi як в активному (на 18 \%), так і в пасивному (на 20 \%) періодах $(p<0,05)$.

Висновки. Серед позитивних ефектів додавання УДХК i L-аргініну до базисної терапії у хворих на IXC і HАХЖП поліпшення показників діастолічної функції, зменшення проявів ішемії міокарда, зниження жорсткості міокарда та кількості шлуночкових і суправентрикулярних екстрасистол, а також збільшення загальної потужності ВНС, нормалізація симпато-парасимпатичного балансу шляхом збільшення впливу парасимпатичної складової на серцево-судинну систему. 


\section{Аинамика структурно-функциональных и вегетативных изменений сердца под влиянием комбинированной терапии урсодезоксихолевой кислотой и L-аргинином у больных ишемической болезнью сердца, ассоциированной с неалкогольной жировой болезнью печени}

\section{Н. С. Михайловская, А. Е. Миняйленко}

Цель работы - изучить влияние комбинации урсодезоксихолевой кислоты и L-аргинина на фоне базисной терапии на структурно-функциональное состояние сердца и показатели вегетативной нервной системы у больных ишемической болезнью сердца, совмещённой с неалкогольной жировой болезнью печени.

Материалы и методы. В исследовании приняли участие 56 пациентов с ИБС и НАЖБП. Пациенты были рандомизированы в две группы. Пациенты 1 группы ( $\mathrm{n}=30)$ получали только базисную терапию ишемической болезни сердца, пациентам 2 группы ( $n=26)$ дополнительно к базисной терапии назначались УДХК и L-аргинин. Всем пациентам проведены суточный мониторинг ЭКГ по Холтеру и двухмерная эхокардиография с импульсно-волновой допплерографией. Обработка статистических данных осуществлялась с помощью пакета программ Statistica 6.0.

Результаты. Во 2 группе после 3 месяцев лечения наблюдали достоверное снижение показателей: индекса жёсткости миокарда - на 45 \%, Va - на 7,4 \%, средней частоты сердечных сокращений как в активном (11,7 \%), так и в пассивном (8\%) периодах, количества (80 \%) и продолжительности (85\%) эпизодов тахикардии, общего количества желудочковых (84 \%) и суправентрикулярных (63 \%) экстрасистол в сутки, продолжительности депрессии сегмента ST (на 55 \%) и продолжительности её максимального эпизода (на 75 \%) и соотношения LF/HF на 24 \% в активном и 27 \% в пассивном периодах наряду с достоверным увеличением показателей: Ve - на 7,4 \%, SDNNi как в активном (на 18 \%), так и в пассивном (на $20 \%$ ) периодах ( $p<0,05)$.

Выводы. Среди положительных эффектов добавления УДХK и L-аргинина к базисной терапии у больных ИБС и НАХБП - улучшение показателей диастолической функции, уменьшение проявлений ишемии миокарда, снижение жёсткости миокарда и количества желудочковых и суправентрикулярных экстрасистол, а также увеличение общей мощности ВНС, нормализация симпато-парасимпатического баланса за счёт увеличения влияния парасимпатической составляющей на сердечно-сосудистую систему.

\section{Introduction}

Coronary heart disease (CHD) continues to occupy the principal place in the structure of morbidity and is one of the leading causes of mortality and population disability [1]. Non-alcoholic fatty liver disease (NAFLD) is considered as one, associated with the metabolic syndrome states, thus significantly increasing the risk of cardiovascular diseases [2].The combination of CHD with NAFLD leads to a number of structural and neurohumoral disorders that affect the course of both diseases through the common pathogenic mechanisms [3].

Structural remodeling of the heart in these comorbid diseases aggravates the cardiovascular prognosis and determines the strategy of patient management [4]. For today, there are convincing shreds of evidence of the liver morphofunctional disorders negative influence on the structural and functional state of the heart in people without cardiac pathology. They chiefly relate to the study of cardio hemodynamics in patients with alcoholic steatohepatitis and liver cirrhosis [5]. It was established that the presence of NAFLD affects the cardiac remodeling due to neurohumoral activation, vegetative changes, volume overload, endothelial dysfunction, insulin resistance, oxidative stress and systemic inflammation [6].

One of the leading roles in the pathogenesis of both coronary heart disease and NAFLD is played by the autonomic dysfunction syndrome, which is based on dysregulation at the level of suprasegmental and segmental structures with the imbalance in the functioning of the sympathetic and parasympathetic parts of the autonomic nervous system [7].

Therefore, the improvement of treatment approaches to correct the structural and functional state of the heart and the autonomic nervous system' violations in patients with coronary heart disease comorbid with the nonalcoholic fatty liver disease is an actual task of modern internal diseases' clinic. It is viewed promising to use the combination of ursodeoxycholic acid (UDCA) and exogenous L-arginine for this purpose against the background of basic therapy in this category of patients.

UDCA is a drug with choleretic, hypolipidemic, anti-inflammatory, as well as vasodilating effects. These properties can be used in the treatment of patients with coronary heart disease with the concomitant nonalcoholic fatty liver disease [8].

$\mathrm{L}$-arginine is a provisionally irreplaceable amino acid that is a substrate for NO synthase [9]. This amino acid has antioxidant, cytoprotective, anti-hypoxic, membrane stabilizing effects. Evidence available at present suggests that the administration of L-arginine improves the endothelial function in patients with angina, heart failure, hypercholesterolemia [10]. In experimental studies, the positive influence of L-arginine on the autonomic nervous system state [11] has been proven.

However, the question of the effectiveness and appropriateness of the administration of UDCA and L-arginine combination against the background of basic therapy in patients with coronary heart disease with the nonalcoholic fatty liver disease requires comprehensive research, thus the direction of our work has been determined.

Purpose: to study the effect of the ursodeoxycholic acid and L-arginine combination on the background of basic therapy on the structural and functional state of the heart and indicators of the autonomic nervous system in patients with coronary heart disease combined with the nonalcoholic fatty liver disease.
Ключевые слова: ишемическая болезнь серлца, неалкогольная жировая болезнь печени, гемодинамика, вегетативная нервная система, урсодезоксихолевая кислота, аргинин.

Патомогия. - 2017. T. 14, № 2(40). C. $142-148$ 


\section{Materials and methods of research}

The research was conducted in the "Zavodsky District Central Clinical Hospital № 4" in Zaporizhzhia, which is the clinical base of the Department of General Practice Family Medicine.

The perspective study in the parallel groups admitted $56 \mathrm{CHD}$ associated with NAFLD patients, age median 56 $(48 ; 60)$. Patients were divided into two groups by the method of block randomization using the table of random numbers of CHD and NAFLD patients $(n=56)$. Patients in the $1^{\text {st }}$ group $(n=30)$ received only basic coronary heart disease therapy, patients in the $2^{\text {nd }}$ group $(n=26)$ in addition to basic therapy were prescribed UDCA at a dose of $20 \mathrm{mg} / \mathrm{kg}$ of body weight per day and $4.2 \%$ solution of L-arginine hydrochloride by intravenous infusion of $100 \mathrm{ml} 1$ time per day for 5 days followed by an oral application of $5 \mathrm{ml}(1 \mathrm{~g})$ three times a day. Duration of treatment was 3 months.

Angina pectoris was diagnosed according to the classification of the Canadian Association of Cardiologists. The presence of morpho-functional signs of non-alcoholic fatty liver disease was established by the ultrasound data according to the standard method.

Criteria for inclusion into the study: informed consent of the patient, presence of documented (verified) CHD and NAFLD. Exclusion criteria: alcoholic or liver cirrhosis, autoimmune and viral hepatitis, decompensated heart failure, acute coronary syndrome, or acute cerebrovascular accidents less than 3 months before the study, congenital or acquired heart defects, systemic, oncological, and autoimmune pathologies.

The studies were conducted in accordance with the Good Clinical Practice and the principles of the Helsinki Declaration. The protocol was approved by the Commission on Bioethics of Zaporizhzhia State Medical University, all the patients involved in the study gave written informed consent to participate in the study.

All patients were given general clinic, anthropometric research, daily ECG monitoring with the definition of myocardial ischemia manifestations, heart rate variability (HRV) with the help of portable cardiovascular system "CardiosensK" (Kharkiv). In the evaluation of HRV indices, the recommendations of the European Society of Cardiology, the North American Society for Cardiac Stimulation and Electrophysiology, the Ukrainian Association of Cardiologists, which describe measurement standards, physiological interpretation, and clinical use of HRV were used. The evaluation of the results was performed on the basis of the summation curves of the ST segment, heart rate deviations, and rhythm disturbance tables.

The following time indices were evaluated: SDNNi, ms - standard deviation of normal NN intervals for 24 hours; RMSSD, ms - standard deviation of the difference between sequential intervals NN; PNN50 \% is the percentage of the successive NN intervals, the difference between which exceeds $50 \mathrm{~ms}$. The following parameters were used for spectral HRV analysis: HF is a high-frequency spectrum component $(0.15-0.4 \mathrm{~Hz})$; LF - low-frequency spectrum component $(0.0410,15 \mathrm{~Hz})$; LF/HF is the coefficient of sympathetic and parasympathetic balance, which reflects the balance of activity of the sympathetic and parasympathetic autonomic system units; LFn \% - relative activity level of the vasomotor center; HFn \% - relative level of parasympathetic control activity; TP - total power of the spectrum; ULF - Ultra Low-Frequency Wave Power (up to $0.0033 \mathrm{~Hz}$ ); VLF is the power of very low-frequency waves $(0.0033-0.04 \mathrm{~Hz})$.

Two-dimensional echocardiography and pulse-wave dopplerography were performed using the Esaote ultrasound scanner «Mylab 40» (Italy) according to the recommendations of the American Society of Echocardiography and the European Association for Echocardiography (2005).

The following parameters were determined $(\mathrm{cm})$ : the size of the right ventricle in the diastole $(\mathrm{RVd}$., $\mathrm{cm})$ and the right atrium in the diastole (RAd, $\mathrm{cm}$ ), the left atrium (LA, cm) and the aorta, the end-diastolic $(\mathrm{LVd}, \mathrm{cm})$ and the end-systolic size (LVs, cm) of the left ventricle (LV), the thickness of the posterior wall (LVPW, $\mathrm{cm}$ ), the thickness of the interventricular membrane (IVS). The end-diastolic volume (LV EDV, ml), the end-systolic volume (LV ESV, ml) were calculated by the Simpson method (1991), the left ventricular ejection fraction (LVEF, \%), the mass of the myocardium (LVM, g) its indexation to the surface area of the body $\left(I M M L V, g / \mathrm{m}^{2}\right)$. Left ventricular myocardial stiffness index (LVMSI) was calculated using the equation: left ventricular end-diastolic pressure (LV EDP) / left ventricular end-diastolic volume (LV EDV).

The relative thickness of the walls of the left ventricular (RWT) was calculated using the formula: RWT = (LVPW + IVS) / LVs, where: LVPW - the thickness of the LV posterior wall in the diastole, IVS - the thickness of the interventricular wall in diastole. For the study of transmitral diastolic blood flow, the maximum velocity of the early $(\mathrm{Ve}, \mathrm{cm} / \mathrm{sec})$ and the late $(\mathrm{Va}, \mathrm{cm} / \mathrm{sec})$ of the filling of the LV, their ratio (Ve/Va, units), and the isovolumic relaxation time (IVRT, ms) were determined.

The evaluation of the LV remodeling types was carried out according to the classification of A. Ganau et al. (1992). From the parasternal position on the short axis at the level of the main vessels for indirect evaluation of the presence of pulmonary hypertension, the pulsed-wave Doppler spectrum of the systolic blood flow through the pulmonary valve (PV) was obtained to calculate the mean pulmonary artery pressure (PAP) using the formula:

$$
\mathrm{PAP}=80-0.5 \times \mathrm{T},
$$

where T - time of systolic flow acceleration on the PV.

Statistical data processing was carried out using the program package Statistica 6.0 (StatSoft Inc., № AXXR712D833214FAN5) according to the generally accepted methodology. The normal distribution was evaluated according to Shapiro-Wilk test. Since all of the analyzed data were different from the normal distribution, to compare the indices in two independent samples the Mann-Whitney U-criterion was used, and Wilcoxon's - in the dependent ones. All data are presented in the form of Median and Quaternary Distribution Me (Q25; Q75). The differences were considered to be significant at $p<0.05$.

\section{Research results}

The dynamics of structural and functional heart parameters in patients with coronary heart disease with concomitant NAFLD under the influence of combination therapy with the addition of UDCA and L-arginine is presented in Table 1. 
Table 1. Dynamics of structural and functional heart parameters under the influence of treatment in patients with coronary heart disease comorbid with NAFLD

\begin{tabular}{|c|c|c|c|c|}
\hline \multirow[t]{2}{*}{$\begin{array}{l}\text { Index, } \\
\text { Unit (of measurement) }\end{array}$} & \multicolumn{2}{|c|}{$\begin{array}{l}\text { The } 1^{\text {st }} \text { subgroup Basic therapy } \\
(n=30)\end{array}$} & \multicolumn{2}{|c|}{$\begin{array}{l}\text { The } 2^{\text {nd }} \text { subgroup Basic therapy } \\
\text { with the addition of UDCA and L-arginine } \\
(n=26)\end{array}$} \\
\hline & Before treatment & In 3 months & Before treatment & In 3 months \\
\hline LV RWT, un. & $\begin{array}{l}0.52 \\
(0.42 ; 0.56)\end{array}$ & $\begin{array}{l}0.51 \\
(0.42 ; 0.56)\end{array}$ & $\begin{array}{l}0.52 \\
(0.50 ; 0.54)\end{array}$ & $\begin{array}{l}0.47 \\
(0.43 ; 0.48)\end{array}$ \\
\hline Aorta, cm & $\begin{array}{l}3.20 \\
(3.10 ; 3.60)\end{array}$ & $\begin{array}{l}3.20 \\
(3.11 ; 3.60)\end{array}$ & $\begin{array}{l}3.30 \\
(2.98 ; 3.40)\end{array}$ & $\begin{array}{l}3.02 \\
(2.71 ; 3.30)\end{array}$ \\
\hline LVd, cm & $\begin{array}{l}4.84 \\
(4.70 ; 5.02)\end{array}$ & $\begin{array}{l}4.82 \\
(4.70 ; 5.00)\end{array}$ & $\begin{array}{l}4.70 \\
(4.60 ; 5.00)\end{array}$ & $\begin{array}{l}4.85 \\
(4.5 ; 5.1)\end{array}$ \\
\hline LV EDV, ml & $\begin{array}{l}120.14 \\
(104.8 ; 127.4)\end{array}$ & $\begin{array}{l}109.62 \\
(102.6 ; 118.2)\end{array}$ & $\begin{array}{l}102.36 \\
(97.33 ; 118.4)\end{array}$ & $\begin{array}{l}101.2 \\
(106.9 ; 178.6)\end{array}$ \\
\hline LVs, cm & $\begin{array}{l}3.30 \\
(3.20 ; 3.70)\end{array}$ & $\begin{array}{l}3.25 \\
(3.00 ; 3.47)\end{array}$ & $\begin{array}{l}3.20 \\
(3.00 ; 3.40)\end{array}$ & $\begin{array}{l}3.52 \\
(3.38 ; 3.82)\end{array}$ \\
\hline LV ESV, ml & $\begin{array}{l}44.13 \\
(40.96 ; 58.12)\end{array}$ & $\begin{array}{l}42.54 \\
(35.0 ; 49.82)\end{array}$ & $\begin{array}{l}42.96 \\
(35.00 ; 47.43)\end{array}$ & $\begin{array}{l}43.43 \\
(43.09 ; 52.73)\end{array}$ \\
\hline LV EDP, mmHg & $\begin{array}{l}20.36 \\
(15.98 ; 23.30)\end{array}$ & $\begin{array}{l}20.26 \\
(15.98 ; 22.5)\end{array}$ & $\begin{array}{l}19.45 \\
(18.21 ; 23.93)\end{array}$ & $\begin{array}{l}18.82 \\
(14.72 ; 24.47)\end{array}$ \\
\hline LV MSI, mmHg/ml & $\begin{array}{l}0.15 \\
(0.12 ; 0.19)\end{array}$ & $\begin{array}{l}0.17 \\
(0.14 ; 0.19)\end{array}$ & $\begin{array}{l}0.20 \\
(0.13 ; 0.23)\end{array}$ & $\begin{array}{l}0.11^{*} \\
(0.08 ; 0.16)\end{array}$ \\
\hline IVS, cm & $\begin{array}{l}1.20 \\
(1.10 ; 1.30)\end{array}$ & $\begin{array}{l}1.20 \\
(1.05 ; 1.30)\end{array}$ & $\begin{array}{l}1.20 \\
(1.20 ; 1.24)\end{array}$ & $\begin{array}{l}1.21 \\
(1.13 ; 1.31)\end{array}$ \\
\hline LVPW, cm & $\begin{array}{l}1.30 \\
(1.12 ; 1.30)\end{array}$ & $\begin{array}{l}1.25 \\
(1.12 ; 1.30)\end{array}$ & $\begin{array}{l}1.23 \\
(1.20 ; 1.30)\end{array}$ & $\begin{array}{l}1.24 \\
(1.11 ; 1.29)\end{array}$ \\
\hline LVEF, \% & $\begin{array}{l}50.00 \\
(44.00 ; 55.00)\end{array}$ & $\begin{array}{l}50.00 \\
(45.00 ; 55.00)\end{array}$ & $\begin{array}{l}51.00 \\
(47.00 ; 57.00)\end{array}$ & $\begin{array}{l}54.00 \\
(50.00 ; 59.50)\end{array}$ \\
\hline LVM, g & $\begin{array}{l}217 \\
(200 ; 226)\end{array}$ & $\begin{array}{l}213 \\
(198 ; 226)\end{array}$ & $\begin{array}{l}222 \\
(200 ; 266)\end{array}$ & $\begin{array}{l}232 \\
(217 ; 235)\end{array}$ \\
\hline IMM LV, g/m² & $\begin{array}{l}112 \\
(106 ; 125)\end{array}$ & $\begin{array}{l}109 \\
(101 ; 122)\end{array}$ & $\begin{array}{l}111 \\
(106 ; 121)\end{array}$ & $\begin{array}{l}112 \\
(106 ; 115)\end{array}$ \\
\hline $\mathrm{RVd}, \mathrm{cm}$ & $\begin{array}{l}1.80 \\
(1.70 ; 2.00)\end{array}$ & $\begin{array}{l}1.80 \\
(1.70 ; 2.00)\end{array}$ & $\begin{array}{l}1.7250 \\
(1.70 ; 1.80)\end{array}$ & $\begin{array}{l}2.0 \\
(1.8 ; 2.1)\end{array}$ \\
\hline RVWd, cm & $\begin{array}{l}0.33 \\
(0.26 ; 0.40)\end{array}$ & $\begin{array}{l}0.28 \\
(0.26 ; 0.40)\end{array}$ & $\begin{array}{l}0.31 \\
(0.30 ; 0.42)\end{array}$ & $\begin{array}{l}0.30 \\
(0.28 ; 0.40)\end{array}$ \\
\hline $\mathrm{Ve}, \mathrm{m} / \mathrm{s}$ & $\begin{array}{l}53.00 \\
(47.00 ; 68.00)\end{array}$ & $\begin{array}{l}50.50 \\
(47.50 ; 62.00)\end{array}$ & $\begin{array}{l}50.00 \\
(40.00 ; 55.00)\end{array}$ & $\begin{array}{l}54.00^{*} \\
(50.00 ; 73.00)\end{array}$ \\
\hline $\mathrm{Va}, \mathrm{m} / \mathrm{s}$ & $\begin{array}{l}68.00 \\
(64.00 ; 71.00)\end{array}$ & $\begin{array}{l}67.50 \\
(63.50 ; 70.00)\end{array}$ & $\begin{array}{l}69.00 \\
(60.00 ; 87.00)\end{array}$ & $\begin{array}{l}66.00^{*} \\
(50.00 ; 83.00)\end{array}$ \\
\hline $\mathrm{Ve} / \mathrm{Va}$ & $\begin{array}{l}0.79 \\
(0.68 ; 1.01)\end{array}$ & $\begin{array}{l}0.84 \\
(0.70 ; 1.03)\end{array}$ & $\begin{array}{l}0.81 \\
(0.67 ; 0.88)\end{array}$ & $\begin{array}{l}0.78 \\
(0.64 ; 1.27)\end{array}$ \\
\hline IVRT & $\begin{array}{l}104.0 \\
(100.0 ; 111.0)\end{array}$ & $\begin{array}{l}100.0 \\
(100.0 ; 104.0)\end{array}$ & $\begin{array}{l}108.0 \\
(100.0 ; 117.0)\end{array}$ & $\begin{array}{l}100.50 \\
(95.5 ; 115.5)\end{array}$ \\
\hline $\mathrm{PAP}, \mathrm{mmHg}$ & $\begin{array}{l}12.00 \\
(12.00 ; 15.00)\end{array}$ & $\begin{array}{l}12.00 \\
(12.00 ; 17.00)\end{array}$ & $\begin{array}{l}12.00 \\
(12.00 ; 15.00)\end{array}$ & $\begin{array}{l}12.00 \\
(13.00 ; 15.00)\end{array}$ \\
\hline
\end{tabular}

*: the probability of indicators difference compared to the initial level is statistically significant;

$\#$ : the probability of difference in the $1^{\text {st }}$ and $2^{\text {nd }}$ groups in three months of treatment is statistically significant.

In the dynamics of observation in 3 months of treatment in patients with CHD combined with NAFLD, the LV MSI decreased by $45 \%(p<0.05)$. There was also a tendency towards a decrease of LV EDV, LV EDP, and an increase of LV EF. Changes in other parameters of structural adjustment of heart in patients of both groups during treatment did not reach the level of statistical probability.

In the analysis of transmitral blood flow rates, a significant decrease in the maximum rate of LV filling in the left atrium systole by $10.45 \%$ was observed and an increase in the maximum speed of early diastolic filling by $7.40 \%$ $(p<0.05)$ was estimated. At the same time, there was a tendency to the decrease of the Ve/Va ratio and the time of isovolumetric relaxation of the left ventricle. The obtained data reflect the UDCA and L-arginine positive effect on the diastolic function of the left ventricle.
In patients of the $1^{\text {st }}$ group, in 3 months of treatment, no reliable changes in the studied parameters were found. Only a tendency towards a decrease in the LV EDV, LVs and IVRT was noted. After 3 months of treatment in the patients of the $2^{\text {nd }}$ group, compared with patients in the $1^{\text {st }}$ group, the lower LV MSI levels by $35 \%$, LV EDV by $8 \%$, LV EDP by $7 \%$ and the $8 \%$ higher LV EF $(p<0.05)$ were observed.

The results of daily ECG monitoring in the dynamics of observation in 3 months are shown in Table 2.

According to the results of daily ECG monitoring in patients receiving supplemental therapy with UDCA and L-arginine against the baseline therapy, there was a decrease in the mean heart rate in both the active $(11 \%)$ and the passive ( $8 \%$ ) periods in the dynamics of treatment. The number (by $80 \%$ ) and duration (by $85 \%$ ) 
Table 2. Dynamics of indicators of ectopic cardiac activity in patients with coronary heart disease comorbid with NAFLD against the background of baseline therapy with the addition of UDCA and L-arginine

\begin{tabular}{|c|c|c|c|c|}
\hline \multirow[t]{2}{*}{$\begin{array}{l}\text { Index, } \\
\text { Unit (of measurement) }\end{array}$} & \multicolumn{2}{|c|}{$\begin{array}{l}\text { The } 1^{\text {st }} \text { subgroup Basic therapy } \\
(n=30)\end{array}$} & \multicolumn{2}{|c|}{$\begin{array}{l}\text { The } 2^{\text {nd }} \text { subgroup Basic therapy } \\
\text { With the addition of UDCA and L-arginine } \\
(n=26)\end{array}$} \\
\hline & Before treatment & In 3 months & Before treatment & In 3 months \\
\hline Average heart rate over the entire period, beats per min. & $\begin{array}{l}70.5 \\
(61.0 ; 75.0)\end{array}$ & $\begin{array}{l}70.0 \\
(67.0 ; 77.0)\end{array}$ & $\begin{array}{l}68.5 \\
(60.5 ; 74.0)\end{array}$ & $\begin{array}{l}61 \\
(60 ; 65)^{*}\end{array}$ \\
\hline The average heart rate during the day, beats per min. & $\begin{array}{l}74.5 \\
(62.0 ; 80.0)\end{array}$ & $\begin{array}{l}75.5 \\
(68.0 ; 83.0)\end{array}$ & $\begin{array}{l}72.5 \\
(63.0 ; 79.5)\end{array}$ & $\begin{array}{l}64 \\
(63 ; 72)^{\star \#}\end{array}$ \\
\hline Circadian Index & $\begin{array}{l}1.16 \\
(1.13 ; 1.22)\end{array}$ & $\begin{array}{l}1.20 \\
(1.1 ; 1.24)\end{array}$ & $\begin{array}{l}1.20 \\
(1.07 ; 1.26)\end{array}$ & $\begin{array}{l}1.19 \\
(1.12 ; 1.21)\end{array}$ \\
\hline Minimum heart rate throughout the period, beats per min. & $\begin{array}{l}50.0 \\
(47.0 ; 55.0)\end{array}$ & $\begin{array}{l}49.0 \\
(46.0 ; 62.0)\end{array}$ & $\begin{array}{l}47 \\
(44.5 ; 48.5)\end{array}$ & $\begin{array}{l}48 \\
(45 ; 64)\end{array}$ \\
\hline Maximum heart rate throughout the period, beats per min. & $\begin{array}{l}109.0 \\
(97.0 ; 126.0)\end{array}$ & $\begin{array}{l}99.0 \\
(89.0 ; 120)\end{array}$ & $\begin{array}{l}129 \\
(97.5 ; 143)\end{array}$ & $\begin{array}{l}97 \\
(88 ; 101)^{*}\end{array}$ \\
\hline Number of tachycardia episodes, episodes per 24 hours & $\begin{array}{l}24.5 \\
(13.0 ; 90.0)\end{array}$ & $\begin{array}{l}14.0 \\
(11.0 ; 68.0)\end{array}$ & $\begin{array}{l}60 \\
(3 ; 173)\end{array}$ & $\begin{array}{l}12 \\
(3 ; 17)^{*}\end{array}$ \\
\hline Tachycardia, minutes & $\begin{array}{l}39.0 \\
(2.0 ; 163.0)\end{array}$ & $\begin{array}{l}22.5 \\
(16.0 ; 118)\end{array}$ & $\begin{array}{l}83.5 \\
(3.25 ; 266.5)\end{array}$ & $\begin{array}{l}13 \\
(1 ; 23)^{* \#}\end{array}$ \\
\hline Ventricular extrasystoles, episodes per 24 hours & $\begin{array}{l}63 \\
(20 ; 326)\end{array}$ & $\begin{array}{l}54.5 \\
(13 ; 248)\end{array}$ & $\begin{array}{l}55 \\
(2 ; 331)\end{array}$ & $\begin{array}{l}8 \\
(1 ; 54)^{* \#}\end{array}$ \\
\hline Supraventricular extrasystole, episodes per 24 hours & $\begin{array}{l}119 \\
(35 ; 173)\end{array}$ & $\begin{array}{l}124 \\
(60.0 ; 233)\end{array}$ & $\begin{array}{l}94.5 \\
(75 ; 223)\end{array}$ & $\begin{array}{l}63.5 \\
(39 ; 119)^{\star *}\end{array}$ \\
\hline The duration of ST depression, minutes per 24 hours & $\begin{array}{l}16 \\
(6 ; 18)\end{array}$ & $\begin{array}{l}12 \\
(7 ; 16)\end{array}$ & $\begin{array}{l}13.5 \\
(7.75 ; 23)\end{array}$ & $\begin{array}{l}6.0 \\
(3.5 ; 8.0)^{\text {*\# }}\end{array}$ \\
\hline ST depression, uV & $\begin{array}{l}169 \\
(142 ; 184)\end{array}$ & $\begin{array}{l}175 \\
(139 ; 225)\end{array}$ & $\begin{array}{l}167 \\
(120 ; 225)\end{array}$ & $\begin{array}{l}150 \\
(125 ; 185)\end{array}$ \\
\hline Episode of maximum ST depressionduration, minutes & $\begin{array}{l}8 \\
(4 ; 13)\end{array}$ & $\begin{array}{l}5.75 \\
(4 ; 10.5)\end{array}$ & $\begin{array}{l}8 \\
(4 ; 8)\end{array}$ & $\begin{array}{l}2 \\
(2 ; 4)^{\star \#}\end{array}$ \\
\hline Maximum ST depression, uV & $\begin{array}{l}97 \\
(81 ; 110)\end{array}$ & $\begin{array}{l}101 \\
(85 ; 112)\end{array}$ & $\begin{array}{l}88 \\
(87 ; 112)\end{array}$ & $\begin{array}{l}90 \\
(85 ; 115)\end{array}$ \\
\hline
\end{tabular}

*: the probability of indicators difference compared to the initial level is statistically significant;

$\#$ : the probability of difference in the $1^{\text {st }}$ and $2^{\text {nd }}$ groups in three month of treatment is statistically significant.

of episodes of tachycardia have significantly decreased. A significant decrease in the total number of ventricular (84\%) and supraventricular (63\%) extrasystoles per day was revealed. Also, in this category of patients, the decrease in the duration of depression of the ST segment (by $55 \%$ ) and the duration of its maximum episode (by $75 \%$ ) was noted.

In 3 months of follow-up in patients of Group 1, a significantly lower number and duration of tachycardia episodes were observed by $43 \%$ and $42 \%$ respectively $(p<0.05)$. There was also a tendency to the reduction of depression duration of the ST segment per day. There were no significant changes in the number of supraventricular and ventricular extrasystoles after treatment in this group. In patients of the $2^{\text {nd }}$ group, compared with patients of the $1^{\text {st }}$ group, after treatment, the heart rate was below the heart rate for the entire observation period by $13 \%$ and heart rate in the active period by $15 \%(p<0.05)$. The number of episodes in the group of tachycardia did not differ significantly, however, the duration of episodes of tachycardia $(p<0.05)$ was significantly lower (by $42 \%$ ). Also, in patients of the $2^{\text {nd }}$ group, fewer episodes of ventricular and supraventricular extrasystoles were noted in 6.75 and 1.95 times, respectively, compared to patients in group $1(p<0.05)$. In patients who received additional UDCA and L-arginine in 3 months of treatment, the total duration of ST-segment depression was 2 times lower and the duration of its maximum episode was 2.87 times $(p<0.05)$.
The dynamics of indicators of heart rate variability in patients with coronary heart disease comorbid with NAFLD is given in Table 3.

After 3 months of treatment, patients with additional UDCA and L-arginine experienced an increase in SDNNi in both active $(18 \%)$ and passive $(20 \%)$ periods $(p<0.05)$. There was a decrease in the LF/HF ratio by $24 \%$ in the active and $27 \%$ in the passive period $(p<0.05)$ due to a possible decrease in the contribution of the sympathetic component and an increase in the activity of the parasympathetic component.

Patients receiving only baseline therapy observed a significant increase only in the HF index of active period (by $17 \%$ ). Patients in the $2^{\text {nd }}$ group compared with patients in group 1 after 3 months of treatment had higher SDNNi values in the active period by $10 \%$ and in the passive period by $12 \%$; HF in the active period by $20 \%(p<0.05)$. Also, the LF/HF ratio was lower by $16 \%$ in the daytime and by $39 \%$ in the night period $(p<0.05)$.

The obtained data coincide with the results of other researchers [12-14]. The study of M. Kielar et al. (2004) shows that the regular use of L-arginine improves the general state of patients with coronary heart disease, reduces the frequency of angina attacks, decreases the dose of nitrates, and increases the tolerance to physical activity [15]. In the work of O.V. Kraydashenko et al. (2012) data are obtained on the reduction of duration and severity of episodes of myocardial ischemia, correlated 
with the restoration of the functional state of the vascular endothelium, in patients receiving L-arginine in the integrated therapy of coronary artery disease [16]. M.A. Tereshchinskaya (2012) noted that for now there is evidence that the pathway L-arginine-NO-cGMP plays an important neuro-modulating role in the functioning of the autonomic nervous system - increases the vagal effect and inhibits its sympathetic component [17].

A. Ya. Bazilevich et al. (2011) showed that the use of ursodeoxycholic acid in patients with coronary heart disease and post-infarction cardiosclerosis in combination with nonalcoholic fatty liver disease leads to a significant improvement in the left ventricular myocardial function and improvement of remodeling of the left heart and central hemodynamics during the year of treatment [14]. In an experimental study by M. Miragoli et al. (2011), the cardioprotective role of UDCA and its anti-arrhythmogenic effect was studied. The researchers found that UDCA protects against ICP-induced arrhythmias (arrhythmias due to intrahepatic cholestasis of pregnancy), directly by hyperpolarization of myofibroblasts [18].

Thus, the positive effects of adding UDCA and L-arginine to baseline therapy in patients with coronary artery disease and NAFLD include improved diastolic function, decreased myocardial ischemia, decreased myocardial stiffness and the number of ventricular and supraventricular extrasystoles, as well as increased total VPS, normalization of the sympathetic-parasympathetic balance by increasing the parasympathetic component of the cardiovascular system.

\section{Conclusions:}

1. The addition of ursodeoxycholic acid and L-arginine to basic therapy in patients with coronary heart disease comorbid with the nonalcoholic fatty liver disease is accompanied by a decrease in the left ventricular myocardium stiffness index and an improvement in the diastolic function.

2. Under the influence of basic therapy with the addition of ursodeoxycholic acid and L-arginine in patients with ischemic heart disease and non-alcoholic fatty liver disease, there is a decrease in the severity of manifestations of myocardial ischemia and the number of ventricular and supraventricular extrasystoles against the normalization of the sympathetic and parasympathetic balance of the autonomic nervous system.

Prospects for further research: to study the effects of combined therapy of UDCA and L-arginine on the state of endothelial dysfunction and vascular remodeling in patients with coronary artery disease and NAFLD.

\section{References}

[1] Kovalenko, V. M., \& Kornatskyi, V. M. (2016). Problemy zdorovia i medychnoi dopomohy ta model pokrashchennia $v$ suchasnykh umovakh [Problems of health and medical care and the model of improvement in modern conditions]. Kyiv. [in Ukrainian].

[2] Babak, O. Ya., Kolesnikova, Ye. V., Shut, I. V., Kurinnaya, Ye. G., \& Sytnic, K. A. (2013). Vliyanie geneticheskogo polimorfizma na formirovanie nealkogol'noj zhirovoj bolezni pecheni [Effect of genetic polymorphism on the formation of non-alcoholic fatty liver disease]. Hastroenterolohiia, 1(47), 54-59. [in Russian].

[3] Kolesnikova, O. V. (2014). Sovremennyj paciyent s zabolevaniem i patologiej serdechno-sosudistoj sistemy: kakoj vybor sdelat'? [The modern
Table 3. Dynamics of cardiac rhythm variability in patients with coronary heart disease comorbid with NAFLD, against the background of baseline therapy with the addition of UDCA and L-arginine

\begin{tabular}{|c|c|c|c|c|}
\hline \multirow[t]{2}{*}{$\begin{array}{l}\text { Index, } \\
\text { Unit } \\
\text { (of measure- } \\
\text { ment) }\end{array}$} & \multicolumn{2}{|l|}{$\begin{array}{l}\text { The } 1^{\text {st }} \text { subgroup } \\
\text { Basic therapy } \\
(n=30)\end{array}$} & \multicolumn{2}{|c|}{$\begin{array}{l}\text { The } 2^{\text {nd }} \text { subgroup } \\
\text { Basic therapy with the addition } \\
\text { of UDCA and L-arginine } \\
\text { ( } n=26 \text { ) }\end{array}$} \\
\hline & Before treatment & In 3 months & \multicolumn{2}{|c|}{ Before treatment In 3 months } \\
\hline \multicolumn{5}{|l|}{ Active period } \\
\hline $\mathrm{mRR}, \mathrm{ms}$ & $\begin{array}{l}839 \\
(751 ; 967)\end{array}$ & $\begin{array}{l}947 \\
(837 ; 966)\end{array}$ & $\begin{array}{l}810 \\
(752 ; 878)\end{array}$ & $\begin{array}{l}834 \\
(775 ; 966)\end{array}$ \\
\hline SDNNi, ms & $\begin{array}{l}47.15 \\
(39.05 ; 69.45)\end{array}$ & $\begin{array}{l}46.30 \\
(36.90 ; 57.90)\end{array}$ & $\begin{array}{l}41.40 \\
(32.95 ; 43.40)\end{array}$ & $\begin{array}{l}50.60 \\
(44.30 ; 58.90)^{* \#}\end{array}$ \\
\hline RMSSD, ms & $\begin{array}{l}26.5 \\
(18 ; 44)\end{array}$ & $\begin{array}{l}20 \\
(17 ; 21)\end{array}$ & $\begin{array}{l}16.0 \\
(12 ; 20.5)\end{array}$ & $\begin{array}{l}26 \\
(19 ; 28)\end{array}$ \\
\hline pNN50, \% & $\begin{array}{l}2.6 \\
(1.4 ; 3.75)\end{array}$ & $\begin{array}{l}2.1 \\
(1.7 ; 4.5)\end{array}$ & $\begin{array}{l}1.0 \\
(0.15 ; 1.65)\end{array}$ & $\begin{array}{l}1.65 \\
(1.1 ; 2.85)\end{array}$ \\
\hline $\mathrm{TP}, \mathrm{ms}^{2}$ & $\begin{array}{l}3114.5 \\
(2361 ; 4781)\end{array}$ & $\begin{array}{l}2111 \\
(1337 ; 3308)\end{array}$ & $\begin{array}{l}1697 \\
(1255 ; 1863)\end{array}$ & $\begin{array}{l}2544 \\
(1931 ; 3367)\end{array}$ \\
\hline ULF, $\mathrm{ms}^{2}$ & $\begin{array}{l}799 \\
(624.5 ; 1155)\end{array}$ & $\begin{array}{l}781 \\
(499 ; 905)\end{array}$ & $\begin{array}{l}606 \\
(331 ; 763)\end{array}$ & $\begin{array}{l}793 \\
(613 ; 1023)\end{array}$ \\
\hline VLF, $\mathrm{ms}^{2}$ & $\begin{array}{l}1362 \\
(1121.5 ; 1937.5)\end{array}$ & $\begin{array}{l}947 \\
(598 ; 1483)\end{array}$ & $\begin{array}{l}701 \\
(414.5 ; 829.5)\end{array}$ & $\begin{array}{l}1149 \\
(900 ; 1714)\end{array}$ \\
\hline $\mathrm{LF}, \mathrm{ms}^{2}$ & $\begin{array}{l}335 \\
(216 ; 440)\end{array}$ & $\begin{array}{l}360 \\
(226 ; 436)\end{array}$ & $\begin{array}{l}231 \\
(155 ; 344)\end{array}$ & $\begin{array}{l}344 \\
(294 ; 761)\end{array}$ \\
\hline LFn, \% & $\begin{array}{l}74.9 \\
(56.45 ; 82.2)\end{array}$ & $\begin{array}{l}73.8 \\
(67.8 ; 79.7)\end{array}$ & $\begin{array}{l}75.4 \\
(65 ; 84.5)\end{array}$ & $\begin{array}{l}72.6 \\
(62.7 ; 80.4)\end{array}$ \\
\hline $\mathrm{HF}, \mathrm{ms}^{2}$ & $\begin{array}{l}105 \\
(90.5 ; 197)\end{array}$ & $\begin{array}{l}123 \\
(90 ; 139)^{*}\end{array}$ & $\begin{array}{l}79.0 \\
(36.5 ; 121.5)\end{array}$ & $\begin{array}{l}147.0 \\
(92 ; 304)^{\star \#}\end{array}$ \\
\hline $\mathrm{HFn}, \%$ & $\begin{array}{l}25.1 \\
(17.8 ; 43.55)\end{array}$ & $\begin{array}{l}26.2 \\
(20.3 ; 32.2)\end{array}$ & $\begin{array}{l}24.6 \\
(15.45 ; 35)\end{array}$ & $\begin{array}{l}20.1 \\
(15.6 ; 35.3)\end{array}$ \\
\hline $\mathrm{LF} / \mathrm{HF}$ & $\begin{array}{l}3.0 \\
(1.3 ; 4.7) \\
\end{array}$ & $\begin{array}{l}2.8 \\
(2.1 ; 3.9) \\
\end{array}$ & $\begin{array}{l}3.1 \\
(1.9 ; 5.5)\end{array}$ & $\begin{array}{l}2.3 \\
(1.7 ; 4.1)^{\star \#}\end{array}$ \\
\hline \multicolumn{5}{|c|}{ Passive period } \\
\hline $\mathrm{mRR}, \mathrm{ms}$ & $\begin{array}{l}991.5 \\
(937 ; 1002)\end{array}$ & $\begin{array}{l}1070 \\
(1010 ; 1137)\end{array}$ & $\begin{array}{l}932.0 \\
(865.5 ; 1053.5)\end{array}$ & $\begin{array}{l}915.0 \\
(951 ; 1116)\end{array}$ \\
\hline SDNNi, ms & $\begin{array}{l}43 \\
(41.85 ; 50)\end{array}$ & $\begin{array}{l}46.5 \\
(42.2 ; 45)\end{array}$ & $\begin{array}{l}42.000 \\
(29.5 ; 52.4)\end{array}$ & $\begin{array}{l}52.400 \\
(50 ; 70)^{\star \#}\end{array}$ \\
\hline RMSSD, ms & $\begin{array}{l}28.5 \\
(24 ; 59.5)\end{array}$ & $\begin{array}{l}24 \\
(22 ; 32)\end{array}$ & $\begin{array}{l}22.0 \\
(18 ; 28.5)\end{array}$ & $\begin{array}{l}24.0 \\
(16 ; 27)\end{array}$ \\
\hline pNN50, \% & $\begin{array}{l}3.65 \\
(3.2 ; 12.45)\end{array}$ & $\begin{array}{l}3.3 \\
(3 ; 12.9)\end{array}$ & $\begin{array}{l}3.7 \\
(1.5 ; 4.6)\end{array}$ & $\begin{array}{l}4.25 \\
(1.8 ; 6.3)\end{array}$ \\
\hline TP, $\mathrm{ms}^{2}$ & $\begin{array}{l}2322 \\
(1649.5 ; 3884.5)\end{array}$ & $\begin{array}{l}2672 \\
(1999 ; 3467)\end{array}$ & $\begin{array}{l}1726 \\
(831 ; 2589)\end{array}$ & $\begin{array}{l}1757 \\
(1055 ; 3425)\end{array}$ \\
\hline ULF, $\mathrm{ms}^{2}$ & $\begin{array}{l}447 \\
(330 ; 628)\end{array}$ & $\begin{array}{l}310 \\
(301 ; 496)\end{array}$ & $\begin{array}{l}308 \\
(191.5 ; 369.5)\end{array}$ & $\begin{array}{l}340 \\
(189 ; 595)\end{array}$ \\
\hline $\mathrm{VLF}, \mathrm{ms}^{2}$ & $\begin{array}{l}623 \\
(338 ; 747)\end{array}$ & $\begin{array}{l}877 \\
(522 ; 960)\end{array}$ & $\begin{array}{l}850 \\
(433.5 ; 1177)\end{array}$ & $\begin{array}{l}993 \\
(401 ; 1156)\end{array}$ \\
\hline $\mathrm{LF}, \mathrm{ms}^{2}$ & $\begin{array}{l}610 \\
(413.5 ; 892)\end{array}$ & $\begin{array}{l}668 \\
(319 ; 823)\end{array}$ & $\begin{array}{l}401 \\
(160.5 ; 649.5)\end{array}$ & $\begin{array}{l}426 \\
(310 ; 733)\end{array}$ \\
\hline LFn, \% & $\begin{array}{l}62.9 \\
(52.1 ; 78.15)\end{array}$ & $\begin{array}{l}78.8 \\
(69.5 ; 80.7)\end{array}$ & $\begin{array}{l}69.4 \\
(57.35 ; 80.45)\end{array}$ & $\begin{array}{l}62.1 \\
(54.4 ; 72.8)\end{array}$ \\
\hline $\mathrm{HF}, \mathrm{ms}^{2}$ & $\begin{array}{l}244.5 \\
(177 ; 357.5)\end{array}$ & $\begin{array}{l}216 \\
(130 ; 362)\end{array}$ & $\begin{array}{l}140 \\
(75 ; 240)\end{array}$ & $\begin{array}{l}148 \\
(91 ; 320)\end{array}$ \\
\hline HFn, \% & $\begin{array}{l}22.65 \\
(15.7 ; 32.5)\end{array}$ & $\begin{array}{l}21.2 \\
(19.3 ; 30.5)\end{array}$ & $\begin{array}{l}28.2 \\
(19.55 ; 42.65)\end{array}$ & $\begin{array}{l}26.1 \\
(20.2 ; 45.6)\end{array}$ \\
\hline $\mathrm{LF} / \mathrm{HF}$ & $\begin{array}{l}3.5 \\
(2.1 ; 5.4)\end{array}$ & $\begin{array}{l}3.7 \\
(2.3 ; 4.2)\end{array}$ & $\begin{array}{l}3.1 \\
(1.35 ; 4.25)\end{array}$ & $\begin{array}{l}2.25 \\
(1.2 ; 3.5)^{\star \#}\end{array}$ \\
\hline
\end{tabular}

*: the probability of indicators difference compared to the initial level is statistically significant; $\#$ : the probability of difference in the $1^{\text {st }}$ and $2^{\text {nd }}$ groups in three months of treatment is statistically significant.

patient with liver disease and pathology of cardiovascular system: what choice to make?]. Suchasna hastroenterolohiia, 2(76), 85-94. [in Russian]

[4] Zaitzev, D. N., \& Govorin, A. V. (2013). Vegetativnaya disfunkciya u bol'nykh khronicheskim prostatitom [Vegetative dysfunction in patients with chronic prostatitis]. Vestnik Volgogradskogo gosudarstvennogo medicinskogo universiteta, 1(45), 80-83. [in Russian].

[5] Krahmalova, E. O., \& Kozlov, A. P. (2010). Nealkogol'naya zhyrovaya bolezn' pecheni i serdechno- sosudistaya patologiya. Sovremennyj vzglyad na problemu [Nonalcoholic fatty liver disease and cardiovascular pathology. The modern view on the problem]. Ukrainskyi terapevtychnyi zhurnal, 4, 82-85. [in Russian]. 
[6] Mykhailovska, N. S., \& Miniailenko, L. E. (2016). Osoblyvosti remodeliuvannia miokarda u khvorykh na ishemichnu khvorobu sertsia komorbidnu z nealkoholnoiu zhyrovoiu khvoroboiu pechinky [Myocardial remodeling features in patients with coronary heart disease comorbid with nonalcoholic fatty liver disease]. ScienceRise: MedicalScience, 2/3(19), 9-14. [in Ukrainian]. doi: 10.15587/2313-8416.2016.60797.

[7] Vejn, A. M. (2003). Vegetativnye rasstrojstva. Klinika, diagnostika, lechenie [Autonomic dysfunction. Clinic, diagnosis, treatment]. Moscow: MIA. [in Russian].

[8] Radchenko, O. M. (2012) Nealkoholna zhyrova khvoroba pechinky: problemy likuvannia [Non-alcoholic fatty liver disease: treatment problems]. Racional'naya farmakoterapiya, 3, 9-13. [in Ukrainian]

[9] Lee, C., Li, D., Channon, K., \& Paterson, D. (2009). L-arginine supplementation reduces cardiac noradrenergic neurotransmission in spontaneously hypertensive rats. Journal of Molecular and Cellular Cardiology, 47(1), 149-155. doi: 10.1016/j.yjmcc.2009.03.023.

[10] Lorin, J., Zeller, M., Guilland, J., Cottin, Y., Vergely, C., \& Rochette, L. (2014). Arginine and nitric oxide synthase: Regulatory mechanisms and cardiovascular aspects. Molecular Nutrition \& Food Research, 58(1), 101-116. doi: 10.1002/mnfr.201300033

[11] Khara, M. R., \& Golovach, N. A. (2013). Vplyv L-arhininu na biokhimichn protsesy $v$ miokardi shchuriv riznoi stati pry streptozototsynovomu tsukrovomu diabeti [Effect of I-arginine on biochemical processes in the myocardium of rats of different gender in streptozotocininduced diabetes mellitus]. Klinichna ta eksperymentalna patolohiia, 1(43), 161-165. [in Ukrainian].

[12] Mykhailovska, N. S., \& Kulynych, T. O. (2017). Vplyv ekzohennoho L-arhininu na stan kardiohemodynamiky ta variabelnist sertsevoho rytmu u khvorykh na ishemichnu khvorobu sertsia pislia perenesenoi nehospitalno pnevmonii [Influence of exogenous L-arginine on the state of cardioghemodynamics and heart rate variability in patients with coronary heart disease after postpartum pneumonia]. ScienceRise: MedicalScience, 3(11), 27-34. [in Ukrainian]. doi: 10.15587/2519-4798.2017.97083.

[13] Smuglov, Ye. P., Kuznecov, N. S., Shadchneva, N. A., \& Sakhaltuev, A. D. (2015). Klinicheskie aspekty ispol'zovaniya L-arginina v kompleksnoj terapii stabil'noj IBS [Clinical aspects of the use of L-arginine in the integrated therapy of stable coronary heart disease]. Krymskij zhurnal e'ksperimental'noj i klinicheskoj mediciny, 5, 2(18), 60-64. [in Russian]

[14] Bazylevych, A. Ya.,\& Potashev, S. V. (2011). Vplyv ursodezoksykholevoi kysloty na stan tsentralnoi hemodynamiky, miokardialnoi funktsii ta remodeliuvannia livoho shlunochka u khvorykh iz postinfarktnym kardiosklerozom kombinovanym iz nealkoholnoiu zhyrovoiu khvoroboiu pechinky [Effect of ursodeoxycholic acid on the state of central hemodynamics, myocardial function and remodeling of the left ventricle in patients with postinfarction cardiosclerosis combined with nonalcoholic fatty liver disease]. Klinichna farmatsiia, farmakoterapiia ta medychna standartyzatsiia, 1-2, 47-56. [in Ukrainian].

[15] Kielar, M., Myrcha, P., \& Pleban, E. (2004). New possibilities in treatment of atherosclerosis--increase of nitric oxide synthesis by L-arginine supplementation. Polski Merkuriusz Lekarski, 17(102), 656-660.

[16] Kraidashenko, O. V., \& Shalmina, M. A. (2012). E'ndotelij oposredovannyj antiishemicheskij e'ffekt tivortina $v$ bol'nykh $s$ ishemichesko bolezn'yu serdca pozhilogo i starcheskogo vozrasta [Endothelium derived antiischemic effect of tyvortin in elderly patients with ischemic heart disease]. Visnyk problem biolohii i medytsyny, 2(2), 105-109. [in Russian].

[17] Treschinskaya, M. A. (2012). Antie'jdzhingovyj e'ffekt L-arginina [Anti-aging Effect of L-arginine]. Medicina neotlozhnyh sostoyanij, 3(42), 50-54. [in Russian].

[18] Miragoli, M., Kadir, S., Sheppard, M., Salvarani, N., Virta, M., Wells, S. et al. (2011). A protective antiarrhythmic role of ursodeoxycholic acid in an in vitro rat model of the cholestatic fetal heart. Hepatology, 54(4) 1282-1292. doi: 10.1002/hep.24492.

\section{Information about authors:}

Mykhailovska N. S., MD, PhD, DSc, Professor,

Head of the Department of General Practice - Family Medicine,

Zaporizhzhia State Medical University, Ukraine.

Miniailenko L. Ye., PhD Student at the Department of General

Practice - Family Medicine, Zaporizhzhia State Medical University,

Ukraine.

\section{Відомості про авторів:}

Михайловська Н. С., А-р меА. наук, професор, зав. каф. загальної практики - сімейної меАицини, Запорізький державний медичний університет, Україна.

Міняйленко $\Lambda$. Є., аспірант каф. загальної практики - сімейної медицини, Запорізький державний меАичний університет, Україна.

\section{Сведения об авторах:}

Михайловская Н. С., А-р меА. наук, профессор, зав. каф. общей практики - семейной медицины, Запорожский государственный медицинский университет, Украина.

Миняйленко ^. Е., аспирант каф. общей практики - семейной медицины, Запорожский государственный медицинский университет, Украина.

Конфлікт інтересів: віАсутній.

Conflicts of Interest: authors have no conflict of interest to declare.

Надійшло Ао редакції / Received: 05.06.2017

Після Аоопрацювання / Revised: 07.06.2017

Прийнято Ао Аруку / Accepted: 12.06.2017 